\section{Correspondence on 'Cardiovascular effects of biological versus csDMARD therapy in treatment naive, early rheumatoid arthritis'}

We have read with interest the article by Plein et al that has been published recently in the Annals of Rheumatic Diseases. The article deals with the cardiovascular (CV) effects of biological diseasemodifying antirheumatic drugs (DMARDs) versus conventional synthetic (cs) DMARD therapy in early naïve rheumatoid arthritis (RA) patients. ${ }^{1}$ The authors compared etanercept (ETN) plus methotrexate (MTX) treatment versus MTX treat-to-target (TT) approach in patients with early RA (ERA), without CV disease and maximum one traditional risk factor. All patients underwent CVMR at baseline and after 1 and 2 years thereafter. At diagnosis, patients with ERA had reduced vascular distensibility, evidence of myocardial fibrosis and reduced left ventricular mass. The study revealed the presence of $\mathrm{CV}$ damage at the earliest stage of the disease course and the ability of early intervention to improve vascular stiffness. However, after 1 and 2 years of treatment, ETN+MTX was not superior to MTX-TT therapy. ${ }^{1}$

The evaluation Of CV dysfunction and early treatment in newly RA patients merits special consideration. Indeed, the results of the above study are not surprising, as nowadays the concept of TT and tight control monitoring represents a therapeutic paradigm of modern rheumatology. ${ }^{2}$ Regarding the methods used to evaluate CV dysfunction in ERA patients carotid ultrasonography (CU) represents the method of choice. ${ }^{34}$ We investigated the lipid profile and the intima-media thickness (IMT) measurement in the common carotid artery (CCA) and their modifications after early intervention with MTX and prednisolone in naive ERA patients. More specifically, 58 ERA and 63 healthy individuals without CV diseases and CV risk factors were investigated in a prospective controlled study. At disease diagnosis ERA patients had dyslipidaemia and high atherogenic ratio as well as higher IMT values of the CCA than controls. After 1 year of treatment, the lipid profile normalised and the IMT values reduced significantly. ${ }^{56}$ Thus, in every day clinical practice, an ERA intervention starts with MTX. Additionally, MTX can be combined with other csDMARDs and steroids in a TT approach or/and with bDMARDs. ${ }^{2}$ It has been demonstrated that combination csDAMRDs therapy has beneficial effects not only to control disease activity and inhibiting structural damage progression, but also to reduce morbidity and mortality in ERA patients. ${ }^{8}$ It has been also shown that combination csDMARDs therapy was not inferior to bDMARDs+MTX therapy to control RA disease activity and was less expensive. ${ }^{9}{ }^{10}$

Regarding CV dysfunction, the last years new imaging modalities have been emerged for the detection of CV abnormalities. Between them CT angiography, is a new method to detect atherosclerotic lesions (plaques, stenosis, obstructions) of the coronary arteries in RA patients. ${ }^{11}$ On the other hand CVMR can detected and visualise early and silent heart abnormalities in RA patients. ${ }^{12}$ However, until now the lack of interaction between cardiologists, radiologists and rheumatologists, the lack of experts in the field, the high cost and the time-consuming procedure, have limited both methods to be adapted in every day clinical practice. Nowadays, $\mathrm{CU}$ is an easy, non-invasive, non-expensive and more sensitive method to evaluate $\mathrm{CV}$ dysfunction in ERA patients. ${ }^{13}$

\footnotetext{
Athanasios N Georgiadis, ${ }^{1}$ Eleftherios Pelechas, ${ }^{2}$ Paraskevi V Voulgari, ${ }^{2}$ Alexandros A Drosos ${ }^{1}{ }^{1}$

${ }^{1}$ Rheumatology Clinic, Internal Medicine, University of Ioannina Faculty of Medicine, loannina, Epirus, Greece

${ }^{2}$ Rheumatology Clinic, Department of Internal Medicine, Medical School, University of Ioannina Faculty of Medicine, Ioannina, Epirus, Greece
}

Correspondence to Professor Alexandros A Drosos, Rheumatology Clinic, Internal Medicine, University of Ioannina Faculty of Medicine, Ioannina 45110, Greece; adrosos@cc.uoi.gr

Contributors All authors have contributed equally for the production of the current manuscript.

Funding The authors have not declared a specific grant for this research from any funding agency in the public, commercial or not-for-profit sectors.

Competing interests None declared.

Patient and public involvement Patients and/or the public were not involved in the design, or conduct, or reporting or dissemination plans of this research.

Patient consent for publication Not required.

Provenance and peer review Not commissioned; internally peer reviewed.

(c) Author(s) (or their employer(s)) 2021. No commercial re-use. See rights and permissions. Published by BMJ.

\section{Check for updates}

To cite Georgiadis AN, Pelechas E, Voulgari PV, et al. Ann Rheum Dis Epub ahead of print: [please include Day Month Year]. doi:10.1136/annrheumdis-2021-219891

Received 12 January 2021

Accepted 13 January 2021

\section{Linked}

- http://dx.doi.org/10.1136/annrheumdis-2021-219926

Ann Rheum Dis 2021;0:1. doi:10.1136/annrheumdis-2021-219891

ORCID iD

Alexandros A Drosos http://orcid.org/0000-0002-2232-0326

\section{REFERENCES}

1 Plein S, Erhayiem B, Fent G, et al. Cardiovascular effects of biological versus conventional synthetic disease-modifying antirheumatic drug therapy in treatmentnaïve, early rheumatoid arthritis. Ann Rheum Dis 2020;79:1414-22.

2 Smolen JS, Breedveld FC, Burmester GR, et al. Treating rheumatoid arthritis to target: 2014 update of the recommendations of an international Task force. Ann Rheum Dis 2016:75:3-15

3 González-Gay MA, González-Juanatey C, Llorca J. Carotid ultrasound in the cardiovascular risk stratification of patients with rheumatoid arthritis: when and for whom? Ann Rheum Dis 2012;71:796-8.

4 van Sijl AM, Peters MJ, Knol DK, et al. Carotid intima media thickness in rheumatoid arthritis as compared to control subjects: a meta-analysis. Semin Arthritis Rheum 2011:40:389-97.

5 Georgiadis AN, Papavasiliou EC, Lourida ES, et al. Atherogenic lipid profile is a feature characteristic of patients with early rheumatoid arthritis: effect of early treatment--a prospective, controlled study. Arthritis Res Ther 2006;8:R82.

6 Georgiadis AN, Voulgari PV, Argyropoulou MI, et al. Early treatment reduces the cardiovascular risk factors in newly diagnosed rheumatoid arthritis patients. Semin Arthritis Rheum 2008;38:13-19.

7 Smolen JS, Landewé RBM, Bijlsma JWJ, et al. EULAR recommendations for the management of rheumatoid arthritis with synthetic and biological disease-modifying antirheumatic drugs: 2019 update. Ann Rheum Dis 2020;79:685-99.

8 Poppelaars PBM, van Tuyl LHD, Boers M. Normal mortality of the cobra early rheumatoid arthritis trial cohort after 23 years of follow-up. Ann Rheum Dis 2019;78:586-9.

9 Drosos AA, Pelechas E, Voulgari PV. Treatment strategies are more important than drugs in the management of rheumatoid arthritis. Clin Rheumatol 2020;39:1363-8.

10 Drosos AA, Pelechas E, Kaltsonoudis E, et al. Therapeutic options and costeffectiveness for rheumatoid arthritis treatment. Curr Rheumatol Rep 2020;22:44

11 Karpouzas GA, Malpeso J, Choi T-Y, et al. Prevalence, extent and composition of coronary plaque in patients with rheumatoid arthritis without symptoms or prior diagnosis of coronary artery disease. Ann Rheum Dis 2014;73:1797-804.

12 Mavrogeni S, Markousis-Mavrogenis G, Koutsogeorgopoulou L, et al. Cardiovascular magnetic resonance imaging pattern at the time of diagnosis of treatment naïve patients with connective tissue diseases. Int J Cardiol 2017:236:151-6.

13 Corrales A, Parra JA, González-Juanatey C, et al. Cardiovascular risk stratification in rheumatic diseases: carotid ultrasound is more sensitive than coronary artery calcification score to detect subclinical atherosclerosis in patients with rheumatoid arthritis. Ann Rheum Dis 2013:72:1764-70. 